Research Article

\title{
Effectiveness of community of inquiry based online course: Cognitive, social and teaching presence
}

\author{
Seda Aktı Aslan ${ }^{1}$ and Yiğit Emrah Turgut ${ }^{2}$ \\ ${ }^{1}$ Ministry of National Education, Turkey (ORCID: 0000-0001-9345-6194) \\ ${ }_{2}^{2}$ Recep Tayyip Erdoğan University, Faculty of Education, Turkey (ORCID: 0000-0002-6306-4090)
}

\begin{abstract}
This quasi-experimental study aimed to examine students' community of inquiry perceptions through online learning activities designed based on the community of inquiry model. The participants of the study consisted of 81 freshmen enrolled in two different departments of a Turkish state university. The process for the experimental procedure was carried out as part of the Information Technologies course. Due to the COVID-19 pandemic, the research process was carried out with synchronous distance education. While the control group received instruction through direct instruction and question/answer technique, the experimental group received instruction based on the community of inquiry model. For data collection, a demographic information form and the community of inquiry scale were administered. According to the results, students in the experimental group had significantly higher scores in terms of cognitive and teaching presence compared with the students in the control group. On the other hand, no significant difference was observed between the groups in terms of their social presence scores. Overall, the students in the experimental group had higher community of inquiry score than the students in the control group.
\end{abstract}

Keywords: Community of inquiry model; Teaching presence; Cognitive presence; Social presence; Community of inquiry perception

Article History: Submitted 10 March 2021; Revised 26 July 2021; Published online 6 September 2021

\section{Introduction}

With the rapid shift to online learning environments at all educational levels due to COVID-19 pandemic, it has been discussed how learning activities and interaction in face-to-face learning environments take place in online environments (Horzum, 2015; Kılıç et al., 2016). As a result of these discussions, the community of inquiry model [CoI], which guides online or blended learning environments, came to the fore (Garrison et al., 1999; Vaughan et al., 2013). CoI, which is based on collaborative and constructivist learning perspectives (Garrison et al., 2003), is used to design online learning experiences and to make them meaningful for learners as well as to evaluate their effectiveness (Garrison et al., 1999). This model posits that learning takes place in a community as a result of three elements including social presence, cognitive presence, and teaching presence

Address of Corresponding Author

Seda Aktı Aslan, ICT Teacher, Ministry of Natiaonal Education, Şahinkaya Secondary School, 23000, Elazı̆̆, Turkey.

$\triangle$ sedakti@gmail.com

How to cite: Akt1-Aslan, S. \& Turgut, Y. E. (2021). Effectiveness of community of inquiry based online course: Cognitive, social and teaching presence. Journal of Pedagogical Research, 5(3), 187-197. https://doi.org/10.33902/JPR.2021371365 
(Garrison et al., 1999). According to this model, which was designed to support especially higher education, an online community becomes inquiry community if it becomes cognitively independent and puts social solidarity in the foreground (Rovai, 2001; Romiszowski \& Mason, 2004). Through CoI, the need for individuals with higher self-control, learning skills, and effective communication skills may be met (Davidson-Shivers et al., 2018; Lee \& Martin, 2017) since, according to CoI, a group of individuals collaborates in order to establish critical discourse and reflection to make a consensus via the internet (Öztürk, 2012).

Meaningful and productive educational experiences depend on the organization of learning environments, the verbal communication, and the selection of content in addition to the interaction among cognitive, social, and teaching presence (Garrison \& Arbaugh, 2007; Garrison et al., 2004). The first dimension of the model is cognitive presence [CP]. It is defined as the process of constructing knowledge in online learning environments by conducting research and having discussions for a common goal (Anderson et al., 2007). According to Kanuka and Garrison (2004), $\mathrm{CP}$, which is the degree of constructing meanings with the support through communication, is also a key element of critical thinking. $\mathrm{CP}$ also has an important role in the realization of high-level learning in online learning environments (Öztürk, 2012). CP consists of four stages: triggering events, exploration, integration, and resolution. This process starts with a triggering event in which the feeling of confusion is experienced and lasts until the change in knowledge occurs. In the second stage, learners share their knowledge and experiences by asking questions. As a result, they gain new knowledge and discover problems (Swan et al., 2008; Özyurt \& Özyurt, 2013). In the third phase, learners are expected to make connections among knowledge they have and to develop solutions (Garrison \& Arbaugh, 2007). In the last phase, it is ensured that solutions are produced and decisions including the implementation of new ideas are made.

The second dimension of the model is social presence [SP], which refers to one's ability to reflect himself socially and emotionally in a research community and to feel belonging to the community (Rourke et al., 2001). Online environments are more isolated compared with face-to-face environments. People may not know the other people in the new environment and may feel foreign, which may cause them to experience anxiety and stress. In addition, if this environment is an online environment, this may increase the level of those negative feelings (Öztürk, 2012). As a result of those feelings, one may prefer to be in a real environment in order to feel social presence. $\mathrm{SP}$ is also defined as the ability of individuals in a research community to introduce themselves with the community, to establish purposeful communications in a reliable environment, and to communicate by reflecting their own personal characteristics (Arbaugh et al., 2008). SP consists of three stages: open communication in which students share their emotions, feelings, beliefs, and values; group cohesion in which they develop a commitment to the group they are in; and effective expression which refers to group work to perform and express the tasks given in an online course (Garrison \& Arbaugh, 2007). Studies revealed that SP is the first step for learning to start in online environments and that SP is an important factor that influences CP (Lee, 2014; Tu, 2007). In collective environments, individuals learn in cooperation with each other, discuss and form knowledge together, which is the main driving force in increasing motivation (Öztürk et al., 2017).

The third dimension is teaching presence (TP), which is the process of designing, facilitating, and managing social and cognitive processes by the teacher for students to achieve meaningful and educationally valuable learning outcomes, similar to the teaching process in face-to-face environments (Akyol \& Garrison, 2011; Garrison \& Anderson, 2003; Rourke et al., 2001). It consists of tasks that must be performed by learners in the research community and this dimension is about facilitating, designing, and directing the process of learning. In the educational process, TP is mainly teacher's responsibility. It consists of three stages including the design and organization stage in which the curriculum and methods are determined by the teacher, the facilitating and supporting conversation stage in which individuals share their understandings, and the direct teaching stage which focus on mutual discussions (Garrison \& Arbaugh, 2007). TP is effective in increasing educational goals by supporting SP and CP (Garrison et al., 1999). 
All three dimensions are critical for $\mathrm{CoI}$ and they represent different aspects of education while interacting with each other (Akyol \& Garrison, 2011; Kozan \& Richardson, 2014). While some studies revealed that they have equal roles in the learning process (Garrison \& Anderson, 2003), some other studies reported an opposite result (Garrison et al., 2010). While Kozan and Richardson (2014) stated that CP plays a more dominant role than SP and TP, Szeto (2015) revealed that TP suppressed the others. In addition, Garrison and colleagues (2010) posited that TP plays a key role in the execution and maintenance of CoI. In another study, stated that an effective teaching process in online environments depends on the power of SP. Despite of the different results in the literature, all studies concluded that these three dimensions are critical in shaping educational experiences (Garrison, 2011).

The use of online learning applications in educational environments with increasing momentum made it necessary to develop a theoretical framework for learning environments. With the COVID-19 pandemic, the sharp transition to emergency remote education has also increased the need for online learning environments. Besides, the effectiveness of emergency remote education and success of online learning activities should be examined (Adarkwah, 2021). Although online learning is not a new trend for teachers and students, the opportunities and the issues this rapid shift brought along should be examined (Almaiah et al., 2020; Hodges et al., 2020). More specifically, with all this need, the importance of improving learning experiences in online learning environments and integrating different teaching approaches into these environments has also emerged. Recently, many researchers adapted $\mathrm{CoI}$ in online learning environments to both shape and evaluate learning experiences (Borup et al., 2012; Garrison et al., 2010; Joo et al., 2011; Kozan \& Caskurlu, 2018; Kupczynski et al., 2010). However, only a few studies used CoI as a teaching approach (Szeto, 2015). Considering the results revealing the positive effects of CoI on the effectiveness of online learning environments, the approach used in this study will reveal an alternative approach for teachers who use online learning environments. In this study, it is aimed to find out the effect of online learning activities designed based on CoI on students' community of inquiry perceptions. For this purpose, the following research questions were addressed:

i. Is there any significant difference between the experimental and the control groups in terms of cognitive presence perceptions?

ii. Is there any significant difference between the experimental and the control groups in terms of social presence perceptions?

iii. Is there any significant difference between the experimental and the control groups in terms of teaching presence perceptions?

iv. Is there any significant difference between the experimental and the control groups in terms of community of inquiry perceptions?

\section{Method}

This study is a quasi-experimental study aiming to determine the effect of online learning activities designed based on the inquiry community model as a teaching approach on students' community of inquiry perceptions.

\subsection{Participants and Context}

The participants of the study were 81 freshmen enrolled in two different departments at a university located in the eastern part of Turkey during the 2020-2021 academic year. Since the participants were in two different departments, they were not randomly assigned to be either in control or experimental groups. Therefore, assignment to the control and experimental groups was conducted based on the departments. There were 38 students in the experimental group and 43 students in the control group. Since random assignment was not possible, some demographic information about the participants was examined as suggested by McMillan and Schumacher (2010). Both departments accept students with similar scores and the same type of score in the university entrance exam. While all participants were in the first year of their undergraduate 
education, most of them did not have any distance education experience. Only three students from the experimental group and five students from the control group had distance education experience. The participants had similar Internet and computer usage habits. In short, the students in the experimental and control groups had similar characteristics.

The participants in both groups were registered for the Information Technologies course. Among the units, only two units were identified for this particular study: Office software and survey application. There were four objectives covered in these units (Table 1).

Table 1

Objectives

\begin{tabular}{cl}
\hline No & Objective \\
\hline 1 & Performs basic text editing and formatting using word processing software \\
\hline 2 & Knows the functions of electronic computing software in general \\
\hline 3 & Creates presentations with multimedia support using presentation software \\
\hline 4 & Knows the functions of survey applications in general \\
\hline
\end{tabular}

\subsection{Experimental Procedure}

Due to the COVID-19 pandemic, the courses were held online. Both groups received synchronous instruction through Zoom platform and its audio, video, and screen share features. In addition, course materials and course video records were shared via Google Classroom for students. Each group received 30-minute instruction three times a week for a total of seven weeks. The data was collected after the courses were completed and it took only one week. The control group received teacher-centered instruction through Zoom application. During teaching, the teacher employed direct instruction and question-answer techniques. Also, the teacher of the control group benefited from presentations and videos during instruction. The control group accessed the course materials through Google Classroom. On the other hand, in the experimental group, cooperative learning approach was employed in order to create online community. The course contents in the experimental group were designed based on Fiock's (2020) teaching activities. Fiock (2020) provided teaching strategies to create an effective online community based on the seven principles of Sorensen and Baylen (2009). The strategies used in the experimental group are given in Table 2.

At the first lesson, the objectives of the course were introduced to students. The instructor explained students what to do during the semester in order to have an effective semester. The students also received information about how to reach course materials through Google Classroom and how to use Zoom in general. Each week, certain objectives were chosen and activities were designed based on those objectives. In this context, in both control and experimental groups, the teacher provided theoretical and practical knowledge for the students and employed questionanswer technique in the first lesson. As students answered the questions, they used microphone and camera in order to interact with the instructor. Also, students used the chat feature to ask and/or answer. The instructor benefited from case studies, problem-based examples, and contradictory questions in order to trigger students' thinking during the question/answer sessions in the experimental group. On the other hand, the teacher used only question-answer technique. In the second lesson, students conducted group work on the assignments. For group work, breakout rooms were created by the instructor. In the experimental group, which consisted of 38 students, the teacher created six groups of 6-7 students. While forming the groups, the number of students in each group and gender were taken into account. Group members were able to interact in the breakout rooms by sharing audio, video, and screen. During the group work, the students shared their ideas about the assignment, discussed, and completed the assignment. The instructor, on the other hand, visited the rooms and guided the discussions. During those visits, she frequently expressed the importance of students' participation in group work and their critical view of each other's ideas. Then, the group leaders shared the output with the other groups in the virtual classroom. In the last lesson, students discussed their thoughts about the outputs and the instructor made comments about those thoughts. Also, the instructor gave another assignment for 
students to improve their skills related to the subject. Students received feedback within a week about their assignments. In addition, the instructor answered the questions asked by students during lessons or via e-mail. This process was repeated every week for seven weeks.

Table 2

Teaching strategies used in the experimental group

\begin{tabular}{|c|c|}
\hline Type of presence & Teaching Strategy \\
\hline $\begin{array}{c}\text { Social } \\
\text { Presence }\end{array}$ & $\begin{array}{l}\text { - Encouraging students to share their experiences and beliefs in online } \\
\text { discussions (Richardson et al., 2009). } \\
\text { - Working in teams (Richardson et al., 2009). } \\
\text { - } \text { One-on-one mentoring (Lowenthal \& Dunlap, 2018; Rovai, 2000). } \\
\text { - Referring to students by names (Lowenthal \& Parscal, 2008). } \\
\text { - Encouraging students to respond others' comments and/or to respond to all } \\
\text { responses to their posts (Richardson et al., 2009). } \\
\text { - Designing team-based tasks, problem-based tasks, projects, and small group } \\
\text { - discussions (Richardson et al., 2009). } \\
\text { Providing alternatives for students to communicate with each other through, } \\
\text { for instance, classroom e-mail, asynchronous discussion forum, and virtual } \\
\text { - } \text { social cafe (Peacock \& Cowan, 2016; Stewart, 2017). } \\
\text { Designing online environment to support within and between group learning } \\
\text { - Experiences (Stephens \& Roberts, 2017; Szeto, 2015). } \\
\text { help thining learners the importance of learner-learner interaction in order to } \\
\text { help them appreciate the classmates' perspectives (Stewart, 2017). }\end{array}$ \\
\hline $\begin{array}{l}\text { Cognitive } \\
\text { Presence }\end{array}$ & $\begin{array}{l}\text { - Encouraging teacher-learner interaction (Redmond, 2014). } \\
\text { - Encouraging different thinking and multiple perspectives in online discussion } \\
\text { with provocative and open-ended questions (Richardson et al., 2009). } \\
\text { - Providing group work or peer-supported learning experiences (Redmond, } \\
\text { 2014). } \\
\text { - Designing courses so that students can figure out the big ideas and critique } \\
\text { them (Richardson et al., 2009). } \\
\text { - Using self-assessment, practice assignments, simulations, and other interactive } \\
\text { activities to support skill development and convergent thinking (Richardson et } \\
\text { al., 2009). } \\
\text { - Supporting higher-order thinking by asking questions that encourage students } \\
\text { to think (Rovai, 2000). } \\
\text { Designing various and gradual activities every week (Richardson et al., 2009). }\end{array}$ \\
\hline $\begin{array}{l}\text { Teaching } \\
\text { Presence }\end{array}$ & $\begin{array}{l}\text { - Rather than excessive "presence" in online discussions, facilitating students' } \\
\text { interaction (Richardson et al., 2009). } \\
\text { - } \text { Applying the principles of collaborative learning in order to support small } \\
\text { group discussions and collaborative projects (Richardson et al., 2009). } \\
\text { - Structuring collaborative learning activities (Lowenthal \& Parscal, 2008). } \\
\text { - Using team-work strategies (Lowenthal \& Parscal, 2008). } \\
\text { - Providing constructive and on-time feedback to students (Watson et al., 2017). } \\
\text { - Responding e-mails instantly (Lowenthal \& Parscal, 2008). } \\
\text { - Designing online learning resources and materials as one-click away (Dunlap } \\
\text { - E Lowenthal, 2018). } \\
\text { Ensuring that students do not get lost in the online learning environment - } \\
\text { ensuring that they know teacher's expectations from them, what to do, when to } \\
\text { do, and teacher's expectations about the course (Dunlap \& Lowenthal, 2018). }\end{array}$ \\
\hline
\end{tabular}




\subsection{Data Collection Tools}

In order to collect data, a demographic information form and the community of inquiry scale were administered. In the demographic information form, the participants were asked to report their age, gender, experience in distance education, and frequency of computer and internet usage. This form was filled out before the implementation.

The community of inquiry scale was developed by Arbaugh et al. (2008) and adapted into Turkish by Öztürk (2012). The five-point Likert type scale consists of 34 items with three factors. The factors are social presence ( 9 items), cognitive presence (12 items), and teaching presence (13 items). In the original version of the scale, the Cronbach's alpha value was calculated as .97. The reliability of the sub-factors was also calculated as .88, .75 and .92, respectively. The items under the social presence aim to reveal the ability of the participants in the learning community to reflect their personal characteristics in the online discussion environment and to communicate with others. An example item in the sub-factor of the social presence is that "Online discussions helped develop a sense of collaborating with others." The cognitive presence includes items related to the process of constructing the knowledge collaboratively by students in the research and learning community. An example item regarding this factor is that "My thoughts on course discussions and course content helped me understand the main ideas of the course". The items in the sub-factor of the teaching presence which is the last factor were completely structured to show the effect of teacher responsibility. An example item under this factor is that "It helped me learn that the teacher kept the class focused on course work".

\subsection{Data Analysis}

The data was analyzed by using IBM SPSS 20. Before the analysis process, the data were examined to determine whether it was normally distributed. The skewness and kurtosis values were calculated. The values of kurtosis and skewness of the data between -1.96 and +1.96 were sufficient for the Assumption of Normality (Field, 2009). Thus, it was determined that the obtained data in the study showed a normal distribution. In order to compare the control and experimental groups' scores, an independent samples t-test was performed. In order to determine to what extent the statistical difference between the groups affected the dependent variable, the effect size value was also calculated. Cohen (1992) suggested that the effect size value is interpreted as .01 small, .06 medium, and .14 large effect.

\section{Findings}

In this section, the findings regarding the effect of online learning activities on students' perceptions of the inquiry community are presented within the framework of research questions.

\subsection{Findings Related to Students' Cognitive Presence}

In regard to the first research question, an independent samples t-test was used to determine whether there was a significant difference between the $\mathrm{CP}$ levels of the students in the experimental and control groups. The findings are presented in Table 3.

Table 3

Independent samples $t$-test results in terms of groups' $C P$ scores

\begin{tabular}{|c|c|c|c|c|c|c|c|}
\hline Groups & $N$ & $\bar{X}$ & $S D$ & $d f$ & $t$ & $p$ & $\eta^{2}$ \\
\hline Experimental & 38 & 43.06 & 3.81 & 79 & 5.021 & .000 & .242 \\
\hline Control & 43 & 37.58 & 5.67 & & & & \\
\hline
\end{tabular}

According to the results, a significant difference was observed between the control and experimental groups' CP scores $(t(79)=5.021 ; p<.05)$. The students in the experimental group had higher scores $(\bar{X}=43.06)$ than the students in the control group $(\bar{X}=37.58)$. The eta square 
value $\left(\eta^{2}\right)$ was calculated as .242 . This value revealed that the online learning activities conducted within the scope of CoI had a large effect on students' CP.

\subsection{Findings Related to Students' Social Presence}

The second research question was about students' SP scores. In order to determine whether there was a significant difference between the SP levels of the students in the experimental and control groups, an independent samples t-test was performed. The results are provided in Table 4.

Table 4

Independent samples $t$-test results in terms of groups' SP scores

\begin{tabular}{|c|c|c|c|c|c|c|}
\hline Groups & $N$ & $\bar{X}$ & $S D$ & $d f$ & $t$ & $p$ \\
\hline Experimental & 38 & 27.42 & 6.01 & 79 & 1.625 & .108 \\
\hline Control & 43 & 25.53 & 4.38 & & & \\
\hline
\end{tabular}

The results revealed non-significant difference between the groups' SP scores $(t(79)=1.625$; $p>$.05). However, the students in the experimental group had higher scores $(\bar{X}=27.42)$ than the students in the control group $(\bar{X}=25.53)$.

\subsection{Findings Related to Students' Teaching Presence}

To determine whether there was a significant difference between the TP levels of the students in the experimental and control groups, an independent samples t-test was conducted. The results are summarized in Table 5.

Table 5

Independent samples t-test results in terms of groups' TP scores

\begin{tabular}{|c|c|c|c|c|c|c|c|}
\hline Groups & $N$ & $\bar{X}$ & $S D$ & $d f$ & $t$ & $p$ & $\eta^{2}$ \\
\hline Experimental & 38 & 47.66 & 3.82 & 79 & 3.294 & .001 & .121 \\
\hline Control & 43 & 44.49 & 4.72 & & & & \\
\hline
\end{tabular}

A significant difference was observed between the groups $(t(79)=3.294 ; p<.05)$. According to the results, the students in the experimental group had higher scores $(\bar{X}=47.66)$ than the students in the control group $(\bar{X}=44.49)$. The eta square value $\left(\eta^{2}\right)$ was calculated as .121 . The eta square value represents a medium effect of online learning activities conducted within the scope of the community of inquiry model on students' TP.

\subsection{Findings Related to Students' Overall Community of Inquiry Perceptions}

Finally, in order to determine whether there was any difference between the control and experimental groups in terms of their community of inquiry perceptions, an independent samples t-test was conducted and the results are given in Table 6.

Table 6

Independent samples $t$-test results in terms of groups' community of inquiry scores

\begin{tabular}{|c|c|c|c|c|c|c|c|}
\hline Groups & $N$ & $\overline{\bar{X}}$ & $S D$ & $d f$ & $t$ & $p$ & $\eta^{2}$ \\
\hline Experimental & 38 & 118.13 & 11.03 & 79 & 4.099 & .000 & .175 \\
\hline Control & 43 & 107.60 & 11.96 & & & & \\
\hline
\end{tabular}

The results presented in Table 6 shows that a significant difference between the control and experimental groups' community of inquiry scores $(t(79)=4.099 ; p<.05)$ exists. The students' overall scores in the experimental group were higher $(\bar{X}=118.13)$ than the ones in the control group $(\bar{X}=107.60)$. The eta square value $\left(\eta^{2}\right)$ was calculated as .175 . This reveals a large effect of online learning activities conducted within the scope of CoI on students' community of inquiry perceptions. 


\section{Discussion and Conclusion}

The necessity of solving the problems experienced in online learning environments is becoming more critical. Researchers and educators consider $\mathrm{CoI}$ as an alternative solution to those problems. Studies focusing on the effectiveness of $\mathrm{CoI}$ in online learning environments reported positive results (Borup et al., 2012; Caskurlu et al., 2020; Cooper, 2014; De Gagne \& Walters, 2009; Kupczynski et al., 2010; Richardson et al., 2017; Shea et al., 2005). This study also aimed to examine undergraduate students' perceptions towards community of inquiry in online learning environments. Within the scope of this study, the differences between the cognitive, social, and presence levels of the experimental and control groups were examined. The findings should be interpreted considering the limitations of the study. This particular study is limited with the experimental and control group students seeking Bachelor's degree at a university and with the some objectives of the Information Technologies course.

The first finding of the study is the higher cognitive presence scores of the experimental group. This result may be interpreted that the learning activities designed based on the CoI had positive effect on students' cognitive presence perceptions. The details in Anderson and colleagues' definition of cognitive presence (2007) are critical to explain such finding. In this definition, it is emphasized that individuals should conduct research in line with similar goals and discuss findings as a group in order to gain cognitive presence in online learning environments. While the selected teaching activities serve this purpose, they also must reflect on each stage of cognitive presence. The rationale of this is that each stage is linked and complementary to each other. Therefore, teaching activities must be designed in order to carry each stage to the next one. More specifically, as Richardson and colleagues (2009) suggested, provocative and open-ended questions were used in the triggering event phase to encourage students to think deeply. In a similar study, Fiock (2020) combined learning activities considering the stages of cognitive presence and found positive effects on students' cognitive presence perceptions. Considering the critical importance of cognitive presence for high-level learning, the finding of this study is very important. Future studies may replicate the study by using the same learning activities with different sample groups or by using different learning activities. As a result of the future studies, new learning activities may be designed to increase cognitive presence levels of students in online learning environments.

In terms of social presence perceptions of students in the control and experimental groups, no significant difference was found between the groups. However, students in the experimental group had higher scores compared with the students in the control group. Students' social presence perceptions are associated with their identification with a community during their work, communication in a safe environment, and reflection on their individual thoughts. In line with learning activities suggested by Fiock (2020), students were encouraged to share their experiences and beliefs in online discussions and worked in teams (Richardson et al., 2009). In addition, in the virtual classroom and breakout rooms on the Zoom application, students were able to communicate with each other within and between groups and they were frequently reminded the importance of learner-learner interaction in order to respect their friends' perspectives (Stewart, 2017). Despite of these efforts, no significant difference occurred between the control and experimental groups. A possible explanation of this result may be that the participants did not have a chance to meet with their classmates in person. Also, the team works were conducted in only online lessons. In order to increase group cohesion, one of the social presence stages, out-ofclassroom activities may be organized with each group. In addition, the open communication phase may not be fully completed in environments where students feel alienated since such feeling may cause students not to share their feelings, beliefs, and values with the other people. Future studies may include extracurricular activities in order to support group cohesion.

The last critical finding of the study is the significant difference between the control and experimental group in terms of their teaching presence levels in favor of students in the experimental group. In this study, the learning activities were designed based on Fiock's (2020) 
suggestions. For the teaching presence dimension, learning activities with deadlines were designed, students were in the center of discussions, and cooperative learning principles were applied in small group discussions (Garrison et al., 2010; Richardson et al., 2009). In addition, the instructor responded to the students' e-mails promptly and provided instant feedback to the students in the discussions in the chat room (Garrison et al., 2010; Watson et al., 2017). Through these efforts, the three phases of teaching presence, which are the design and organization phase, the facilitating and supporting conversation phase, and the direct teaching phase, were supported. As a result, a significant increase was observed in students' teaching presence in the experimental group. In future studies, alternative learning activities that support teaching presence may be included to experimental processes. Future studies should also examine the effects of learning activities that are designed to include teaching presence, social presence (Garrison et al., 2010), and cognitive presence (Szeto, 2015).

\section{References}

Adarkwah, M. A. (2021). "I'm not against online teaching, but what about us?": ICT in Ghana post Covid19. Education and Information Technologies, 26, 1665-1685. https:// doi.org/10.1007/s10639-020-10331-z

Akyol, Z., \& Garrison, D. R. (2011). Understanding cognitive presence in an online and blended community of inquiry: Assessing outcomes and processes for deep approaches to learning. British Journal of Educational Technology, 42(2), 233-250. https://doi.org/10.1111/j.1467-8535.2009.01029.x

Almaiah, M. A., Al-Khasawneh, A., \& Althunibat, A. (2020). Exploring the critical challenges and factors influencing the E-learning system usage during COVID-19 pandemic. Education and Information Technologies, 25, 5261-5280. https:/ / doi.org/10.1007/s10639-020-10120-8

Arbaugh, J. B., Cleveland-Innes, M., Diaz, S. R., Garrison, D. R., Ice, P., Richardson, J. C., \& Swan, K.P. (2008). Developing a community of inquiry instrument: Testing a measure of the Community of Inquiry framework using a multi-institutional sample. The Internet and Higher Education, 11(3-4), 133-136. https://doi.org/10.1016/j.iheduc.2008.06.003

Borup, J., West, R. E., \& Graham, C. R. (2012). Improving online social presence through asynchronous video. The Internet and Higher Education, 15(3), 195-203. https:/ / doi.org/10.1016/j.iheduc.2011.11.001

Caskurlu, S., Richardson, J. C., Maeda, Y., \& Kozan, K. (2021). The qualitative evidence behind the factors impacting online learning experiences as informed by the community of inquiry framework: A thematic synthesis. Computers $\mathcal{E}$ Education, 165, 104111. https:// doi.org/10.1016/j.compedu.2020.104111

Cohen, J. (1992). A power primer. Psychological Bulletin,112(1), 155-159. https://doi.org/10.1037/00332909.112.1.155

Cooper, V. A. (2014). Creating a community of inquiry in higher education: A practical example and lessons learned. The International Journal of Learning in Higher Education, 20(1), 95-107.

Davidson-Shivers, G. V., Rasmussen, K. L., \& Lowenthal, P. R. (2018). Overview of online instruction and learning environments and communities. In Web-based learning (pp. 3-41). Springer, Cham. https:// doi.org/10.1007/978-3-319-67840-5_1

De Gagne, J. C., \& Walters, K. (2009). Online teaching experience: A qualitative metasynthesis (QMS). MERLOT Journal of Online Learning and Teaching, 5(4), 577-589.

Dunlap, J. C., \& Lowenthal, P. R. (2018). Online educators' recommendations for teaching online: Crowdsourcing in action. Open Praxis, 10(1), 79-89. https:// doi.org/10.5944/openpraxis.10.1.721

Field, A. (2009). Discovering statistics using IBM SPSS statistics. Sage Publications.

Fiock, H. (2020). Designing a community of inquiry in online courses. The International Review of Research in Open and Distributed Learning, 21(1), 135-153. https:/ / doi.org/10.19173/irrodl.v20i5.3985

Garrison, D. R., Anderson, T. \& Archer, W. (1999). Critical inquiry in a text-based environment. The Internet and Higher Education, 2, (2-3), 87-105. https:/ / doi.org/10.1016/S1096-7516(00)00016-6

Garrison, D. R. (2011). E-learning in the 21st century: A framework for research and practice. Taylor \& Francis.

Garrison, D. R., \& Anderson, T. (2003). E-Learning in the 21st Century: A framework for research and practice. RoutledgeFalmer.

Garrison, D. R., Anderson, T., \& Archer, W. (1999). Critical inquiry in a text-based environment: Computer conferencing in higher education. The Internet and Higher Education, 2(2-3), 87-105. https://doi.org/10.1016/S1096-7516(00)00016-6 
Garrison, D. R., Anderson, T., \& Archer, W. (2003). A theory of critical inquiry in online distance education. Handbook of Distance Education, 1, 113-127.

Garrison, D. R., \& Arbaugh, J. B. (2007). Researching the community of inquiry framework: Review, issues, and future directions. The Internet and Higher Education, 10(3), 157-172. https://doi.org/10.1016/j.iheduc.2007.04.001

Garrison, D. R., Cleveland-Innes, M., \& Fung, T. (2004). Student role Adjustment in Online Communities of Inquiry: Model and Instrument Validation. Journal of Asynchronous Learning Networks, 8(2), 61-74.

Garrison, D. R., Cleveland-Innes, M., \& Fung, T. S. (2010). Exploring causal relationships among teaching, cognitive and social presence: Student perceptions of the community of inquiry framework. The Internet and Higher Education, 13(1-2), 31-36. https:// doi.org/10.1016/j.iheduc.2009.10.002

Hodges, C., Moore, S., Lockee, B., Trust, T., \& Bond, A. (2020). The difference between emergency remote teaching and online learning. Educause Review, 27, 1-12.

Horzum, M. B. (2015). Online learning students' perceptions of the community of inquiry based on learning outcomes and demographic variables. Croatian Journal of Education: Hrvatski časopis za odgoj $i$ obrazovanje, 17(2), 535-567. https://doi.org/10.15516/cje.v17i2.607

Joo, Y. J., Lim, K. Y., \& Kim, E. K. (2011). Online university students' satisfaction and persistence: Examining perceived level of presence, usefulness and ease of use as predictors in a structural model. Computers $\mathcal{E}$ Education, 57(2), 1654-1664. https://doi.org/10.1016/j.compedu.2011.02.008

Kanuka, H., \& Garrison, D. R. (2004). Cognitive presence in online learning. Journal of Computing in Higher Education, 15(2), 21-39. https://doi.org/10.1007/BF02940928

Kılıç, S., Horzum, M. B., \& Çakıroğlu, Ü. (2016). Investigating teaching, social and cognitive presence of students in synchronous online environments. Turkish Journal of Computer and Mathematics Education, 7(2), 350-364. https://doi.org/10.16949/turcomat.35549

Kozan, K., \& Caskurlu, S. (2018). On the nth presence for the community of inquiry framework. Computers $\mathcal{E}$ Education, 122, 104-118. https:/ / doi.org/10.1016/j.compedu.2018.03.010

Kozan, K., \& Richardson, J. C. (2014). Interrelationships between and among social, teaching, and cognitive presence. The Internet and Higher Education, 21, 68-73. https:// doi.org/10.1016/j.iheduc.2013.10.007

Kupczynski, L., Ice, P., Wiesenmayer, R., \& McCluskey, F. (2010). Student perceptions of the relationship between indicators of teaching presence and success in online courses. Journal of Interactive Online Learning, 9(1), 23-43.

Lee, S. M. (2014). The relationships between higher order thinking skills, cognitive density, and social presence in online learning. The Internet and Higher Education, 21, 41-52. https://doi.org/10.1016/j.iheduc.2013.12.002

Lee, J., \& Martin, L. (2017). Investigating students' perceptions of motivating factors of online class discussions. International Review of Research in Open and Distributed Learning, 18(5), 148-172. https://doi.org/10.19173/irrodl.v18i5.2883

Lowenthal, P. R., \& Parscal, T. (2008). Teaching presence online facilitates meaningful learning. The Learning Curve, 3(4), 1-2.

Lowenthal, P., \& Dunlap, J. (2018). Investigating students' perceptions of instructional strategies to establish social presence. Distance Education, 39(3), 281-298. https:/ / doi.org/10.1080/01587919.2018.1476844

McMillan, J. H., \& Schumacher, S. (2010). Research in Education: Evidence-Based Inquiry, MyEducationLab Series. Pearson.

Öztürk, E. (2012). An adaptation of the community of inquiry index: The study of validity and reliability. Elementary Education Online, 11(2), 408-422.

Öztürk, E., Erdem, M., \& Deryakulu, D. (2017). The predictive power of social and teaching presence on cognitive presence. Kastamonu Education Journal, 25(4), 1319-1336.

Özyurt, Ö., \& Özyurt, H. (2013). An examination of computer engineering students' perceptions about asynchronous discussion forums. EURASIA Journal of Mathematics, Science and Technology Education, 9(4), 371-378. https://doi.org/10.12973/eurasia.2013.941a

Peacock, S., \& Cowan, J. (2016). From presences to linked influences within communities of inquiry. International Review of Research in Open and Distance Learning, 17(5), 267-283. https://doi.org/10.19173/irrodl.v17i5.2602

Redmond, P. (2014). Reflection as an indicator of cognitive presence. E-Learning and Digital Media, 11(1), 4658. https:// doi.org/10.2304/elea.2014.11.1.46 
Richardson, J. C., Ice, P., \& Swan, K. (2009). Tips and techniques for integrating social, teaching, \& cognitive presence into your courses. Poster session presented at the Conference on Distance Teaching \& Learning, Madison, WI.

Richardson, J. C., Maeda, Y., Lv, J., \& Caskurlu, S. (2017). Social presence in relation to students' satisfaction and learning in the online environment: A meta-analysis. Computers in Human Behavior, 71, 402-417. https://doi.org/10.1016/j.chb.2017.02.001

Romiszowski, A., \& Mason, R. (2004). Computer-mediated communication. In D. H. Jonassen. (Ed.), Handbook of research for educational communications and technology (pp. 397-431). Simon \& Schuster Macmillan.

Rourke, L., Anderson, T., Garrison, D. R., \& Archer, W. (2001). Methodological issues in the content analysis of computer conference transcripts. International Journal of Artificial Intelligence in Education, 12, 8-22.

Rovai, A. P. (2000). Building and sustaining community in asynchronous learning networks. The Internet and Higher Education, 3, 285-297. https:/ / doi.org/10.1016/S1096-7516(01)00037-9

Rovai, A. P. (2001). Classroom community at a distance: A comparative analysis of two ALN-based university programs. The Internet and Higher Education, 4(2), 105-118. https://doi.org/10.1016/S10967516(01)00053-7

Shea, P., Li, C. S., Swan, K., \& Pickett, A. (2005). Developing learning community in online asynchronous college courses: The role of teaching presence. Journal of Asynchronous Learning Networks, 9(4), 59-82.

Sorensen, C. K., \& Baylen, D. M. (2009). Learning online: Adapting the seven principles of good practice to a Web-based instructional environment. In A. Orellana, T. L. Hudgins, \& M. Samonson (Eds.), The perfect online course: Best practices for designing and teaching (pp. 69-86). Information Age Publishing.

Stephens, G. E., \& Roberts, K. L. (2017). Facilitating collaboration in online groups. Journal of Educators Online, 14(1), 1-16.

Stewart, M. K. (2017). Communities of inquiry: A heuristic for designing and assessing interactive learning activities in technology-mediated FYC. Computers and Composition, 45, 67-84. https://doi.org/10.1016/j.compcom.2017.06.004

Swan, K., Shea, P., Richardson, J., Ice, P., Garrison, D., Cleveland-Innes, M. ve Arbaugh, J. (2008). Validating a measurement tool of presence in online communities of inquiry. E-Mentor, 2(24), 1-12.

Szeto, E. (2015). Community of Inquiry as an instructional approach: What effects of teaching, social and cognitive presences are there in blended synchronous learning and teaching? Computers $\mathcal{E}$ Education, 81, 191-201. https:// doi.org/10.1016/j.compedu.2014.10.015

$\mathrm{Tu}, \mathrm{C}$. (2007). How Chinese perceive social presence: An examination of interaction in online learning environment. Educational Media International, 38(1), 45-60. https://doi.org/10.1080/09523980010021235

Vaughan, N. D., Cleveland-Innes, M., \& Garrison, D. R. (2013). Teaching in blended learning environments: Creating and sustaining communities of inquiry. Athabasca University Press.

Watson, F. F., Bishop, M. C., \& Ferdinand-James, D. (2017). Instructional strategies to help online students learn: Feedback from online students. TechTrends, 61, 420-427. https://doi.org/10.1007/s11528-017-0216y 